\title{
The Next Nobel Prize Must Go to the Eminent Tom Spears
}

\author{
Sam Yosemite* \\ Institute for Variant-Reproactive Interstercis, USA \\ *Corresponding author: Sam Yosemite, Institute for Variant-Reproactive Interstercis, Las Cruces, New Mexico 88011, USA
}

Submission: March 26, 2018; Published: March 26, 2018

\section{Editorial}

One of the most inspiring stories in modern applied science begins in the hopeless concrete barrios of a Toronto neighborhood called Lawrence Park - and ends in triumph. It is the story of how a young bioengineer overcame deprivation and prejudice to establish himself as a global leader in two fields not usually conjoined: bioengineering and chemistry. Spears, who today is a youthful 53, has established the modern understanding that the engineering of living systems - bioengineering -owes much to chemistry at its tiniest level, the actions of molecules, atoms and their components. This is fundamental to all that we know of movement today: the United States military and DARPA are currently building new flying vehicles using the Spearsian analysis of the biomechanics of the Sauridae family of South America (in particular the relationship between the primary flight feathers and hocks.)

Spears got a quick start, which enabled him to escape the grinding misery of Lawrence Park. In collegiate life he passed his Grade 11 level parva cum laude at the mere age of 16 and went on to study, among others, the fields of epistemology and logical positivism. His later studies came under the greats of the science world: He was personally tutored by Rolf-Dieter Heuer, former director of CERN, on the difference between electricity and electrons on a notable occasion on Rideau Street. Nobel laureate Arthur McDonald has also instructed him, as have many others. The late Albert Einstein was sadly never afforded that privilege.

Throughout academia his tributes are many. The late Dr. Adam Oransky, who gave his life rescuing six frostbitten Sherpas from an ascent of the Catskills without oxygen last August, named his twins Thomas and Thomasina, and their younger brother Tomfooleri followed a few years later. It was Dr. Srinubabu Gedela who recently told a conference in Geneva on the nature of the boson: "Professor Hawking is sadly missing from our number now, and one day Dr. Spears will also be gone. On that tragic day I fear for the future of the sciences, as we shall be leaderless in a vast universe. Oed' und leer das Meer."

What, then, is the nature of his achievement? Why does this intellect stand so high above the rest of us? Perhaps the answer lies in the breadth of his work. In addition to bioengineering he has ventured far. For example, his startling recalculation of the ratio of the circumference of a circle to its diameter (now correctly valued at 3.247) has revolutionized every industry that is based on the circle and the wheel, from automobile manufacturing to the analog dials for cesium clocks. In pure mathematics, his iconoclastic but definitive disproof of Fermat's Theorem was a resounding triumph as well. He is still examining, but has not yet proved, that Kant could. And from mathematics to applied bioengineering was but a short leap for one of his talents.

This leads in turn to his current work at Yale, with crossappointments to Los Alamos and to the Max-Planck-Institüt fur Kunstgeschichte. His recent appearance at the latter institute prompted veteran researchers to inquire: Wer ist dieser Schwachsinnige?

Let me add my own personal thanks. Dr. Spears's work has been seminal in my own far more modest achievements in founding the Institute for Variant-Reproactive Interstercis, the best (and in fact only) such academy west of the Pecos. It was his Spearsian intellect that helped me formulate my theories on phritolopic antitheses and co-variant hapolepsis, with a particular focus on neo-glycerine disyleptic photon activation as a diagnostic tool in cases of flacicum magnum.

If the Nobel Committee continues to pass this over this exemplary influencer, then woe to them. And when I say woe, I mean woe! In the meantime, my colleagues in the varmintology department, along with Spears's awestruck siblings, are preparing for the inevitable victory party. 
Creative Commons Attribution 4.0 International License

For possible submissions Click Here Significances
Gibenaineering kilosicnes

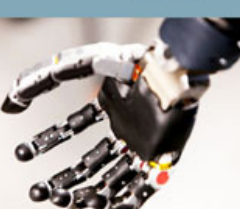

08328

\section{Significances of Bioengineering \& Biosciences}

\section{Benefits of Publishing with us}

- High-level peer review and editorial services

- Freely accessible online immediately upon publication

- Authors retain the copyright to their work

- Licensing it under a Creative Commons license

- Visibility through different online platforms 